\title{
BUILDING INNOVATION CAPABILITIES ON COLLABORATION AND MARKET ORIENTATION FOR IMPROVING MARKETING PERFORMANCE OF WOOD FURNITURE CRAFT
}

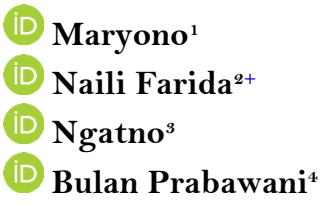

(n)

\section{Article History}

Received: 4 October 2021 Revised: 19 November 2021 Accepted: 7 December 2021 Published: 29 December 2021

\section{Keywords}

Innovation capabilities Market orientation Marketing performance Wood furniture craft Relationship marketing SMEs.

\author{
${ }^{\prime}$ PhD Student, Diponegoro University Jl. Erlangga Barat 7 No. 31, \\ Semarang, Central Java, Indonesia. \\ 'Email:yon fisip@yahoo.co.id Tel: +62 82250392692 \\ ${ }^{2, s, 4}$ Lecturer, Faculty of Social and Political Sciences, Diponegoro University \\ Jl. Prof. Sudarto, Semarang, Central Java, Indonesia. \\ ${ }^{2}$ Email: faridanaili@ymail.com Tel:+628122895448 \\ ${ }^{s}$ Email: Ngatno_fisip@yahoo.co.id Tel: +62 8156502259 \\ ${ }^{4}$ Email: iboel18@yahoo.com Tel: +62811297974.
}

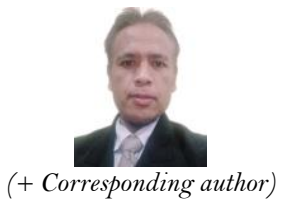

(+ Corresponding author)

\section{ABSTRACT}

This research aims to test the direct influence of market orientation and innovation capabilities collaboration, with relationship marketing orientation and excellence as mediating variables, on the marketing performance of the micro industry of wood furniture handicrafts. The data was collected using questionnaires submitted by 242 people, and the analysis was carried out using SmartPLS software. The significant impact of collaborative innovation ability and relational marketing orientation on market orientation was shown to have no effect on competitive advantage. The innovation capabilities of collaborating are known to have no significant impact on marketing performance. Competitive advantage has a relationship with marketing performance, and relational marketing orientation has a significant impact on the ability of collaborative innovation. It was also found that relationship marketing orientation has a significant effect on marketing performance. This study is related to improving the marketing performance of the micro industry of wood furniture handicrafts, which has a limited scope, so the results of this study can't be generalized. It was also difficult to determine if there was any bias from the respondents. The marketing orientation of relationships and competitive advantages have contributed significantly to marketing performance. The wood furniture handicraft micro industry must improve collaboration capabilities with dealers and customers and use this as a strategic component to improve the marketing performance of the woodcraft industry. The novelty of this research is related to the capability of collaboration innovation, which is able to improve the marketing performance of small industries.

Contribution/Originality: The novelty of this study lies in its analysis of the direct effect of market orientation and collaboration innovation capability, with relationship marketing orientation and competitive advantage as mediating variables, on the marketing performance of the wood furniture micro industry in South Kalimantan.

\section{INTRODUCTION}

The effort to maintain and increase competition require SMEs to have competitive advantage and formulate effective business strategies. According to Ehmke (2008), competitive advantage can be achieved by offering customers greater value through lower prices, or by providing additional benefits and services at the same price. If a company wants to gain a competitive advantage, it has to perform above consumer expectations by providing the best service so that it retains customers and ensures that they will not choose alternative companies (Parasuraman, 
Zeithaml, \& Malhotra, 2005). Along with that, a company must also have the ability to develop its strategic orientation options. Strategic orientation is the direction a company takes in creating the right behavior through superior performance (Singh \& Kumar, 2021; Zhou, Yim, \& Tse, 2005). The dimension of strategy orientation that is often discussed by some researchers and marketing experts is market orientation (Paulraj, Lado, \& Chen, 2008). Market orientation is the perspective of a company's strategy used to achieve sustainable competitive advantage based on the creation and utilization of organizational information as well as the selection of satisfied markets. In order for a company to remain sustainable and beat the competition, it should be able to foster long-term relationships with its stakeholders. Marketing relationships are the basic orientation of creating stronger customer and company relationships in improving performance outcomes, such as sales growth, market share, profitability and customer retention (Xu et al., 2020). According to the research by Farida and Yuniawan (2017) related to relationship marketing by looking at the level of relationship quality, relationship quality benefits the quality of service provided to customers.

The effect of rapid changes in external environmental factors and competition in the global market today, SMEs can not only depend on their own resources, but they are also required to be able to establish business cooperation more closely with external parties through a collaboration network. Collaboration helps to increase the creation, division and transfer of knowledge, and will support a culture capable of making new discoveries and innovations that further impact the organizations' performance. Companies with the capability of collaborative innovation are able to acquire knowledge resources, which will lead to a competitive advantage. Related to this, this research departs on the existence of some controversies regarding the relationship of market orientation with marketing performance. It is necessary to explore empirical research models to fill research gaps that affect market orientation and marketing performance by providing an update on collaborative innovation capabilities.

According to the phenomenon problems of the decrease in marketing performance in SMEs, it is important to collaborate with customers and suppliers to contribute for the process of innovation in wood furniture craft SMEs. Forms of collaborative innovation come from consumers and companies by conducting design activities, joint development, and creation of new products or services (Russo-Spena \& Mele, 2012). Interaction with consumers will also contribute to innovation by ultimately generating demand. There is a principle in innovation, namely the process of value creation, which is done in collaboration with consumers, and rarely does a company have sufficient knowledge, expertise, skills and resources without doing value creation together without learning and accessing resources from consumers or other information (Zheng, Zhang, Ma, Xie, \& Ma, 2011). Collaboration networks can be formed with clients, suppliers, and other companies (competitors) and horizontal networks consisting of research institutes, universities, and governments.

\section{LITERATURE REVIEW}

\subsection{Innovation Capabilities of Collaboration}

A company's capability in a resource-based view is one of the important internal factors in managing resources to achieve competitive advantage. When a company's capabilities are good, then the management of resources will be good, which will enable it to achieve competitive advantage. This means that the key to a company's success in achieving competitive advantage comes from the characteristics within the company itself (Fransisca, 2013).

Companies that want to survive in a competitive and uncertain environment have been forced to develop their own innovation capabilities. The capability of companies to create and exploit external opportunities and build competitive advantages by having the ability to innovate will help them to survive. Innovation is the mechanism by which a company adapts to a dynamic environment and is separated into three categories: organizational innovation, innovation level, and innovation capabilities. Research on the level of innovation explains different types of innovations. This type of innovation becomes incremental, radical and moderate innovation. Growth and achieving success and sustainability is the goal of every company. 
To improve the performance of SMEs, industries needs to emphasize the importance of building collaboration capabilities when innovating. By having a high ability to innovate, a company will be able to respond to the changing environment and develop new capabilities to gain an advantage in business competition. Collaboration competency innovation helps companies to acquire knowledge resources which they can use toward gaining a competitive advantage. Therefore, SMEs in the woodcraft industry must find new ways to increase market share and business performance, and also collaborate on sustainable innovation. One of the key success factors in organizations is product innovation, which is a strategy used to improve business performance and market share (Hassan, Shaukat, Nawaz, \& Naz, 2013).

\subsection{Market Orientation}

Market orientation is the development of market intelligence to meet current and future consumer needs and is a measure of behavior and activity that reflects the implementation of marketing concepts related to organizational learning from customers and competitors. Market orientation is a set of values that put the interests of customers above all else to increase the company's profits over a long period and it is the informal obtainment of customers and competitors through the collection, deployment, and response of market intelligence in response to market share. Market orientation includes three elements: market intelligence as part of providing appropriate market information; dissemination of information provided to all units of the company to develop strategic synergies; and response to market intelligence in each unit of the company through the form of marketing strategies according to the market environment (Deshpandé \& Farley, 1998).

\subsection{Competitive Advantaging}

The increasing competition at every level requires companies to prepare everything in order to be able to grow and survive competition. Competitive advantage includes focusing on developing superior skills and resources. (Day \& Wensley, 1988) explained that competitive advantage can be achieved by creating economic value compared to competitors by generating more benefits through low cost differentiation (Dyhdalewicz \& Widelska, 2017).

\subsection{Relationship Marketing Orientation}

A marketing relationship is characterized by a reciprocal, interdependent, committed, and long-term relationship between the seller and the buyer. The concept of relationship marketing has gotten a lot of research attention from scholars. Business philosophy has undergone a shift from a production orientation to a sales orientation, then to a marketing orientation and eventually to relationship marketing orientation (RMO) (Sin, Tse, Yau, Chow, \& Lee, 2005). The fundamental benefits of RMO create stronger customer relationships that improve performance outcomes such as sales growth, market share, profit, return on investment, and customer retention. Further RMO consists of trust, bonding, communication, shared values, empathy, and reciprocity. Relationship marketing orientation proactively creates, develops and maintains relationships between buyers and sellers in the long term and is mutually beneficial on a company performance level.

\subsection{Marketing Performance}

One of the factors that companies use to measure the impact of their strategy is marketing performance (Ferdinand, 2002). Marketing performance provides three dimensions, namely the company effectiveness, sales growth, and the company's maturity. Marketing performance also includes market share and sales volume achieved by the company (Huhtala, Sihvonen, Frösén, Jaakkola, \& Tikkanen, 2014). Performance is measured through sales volume, achievement of revenue goals, achievement of sales growth and achievement of market share. 
The innovation capability concepts and study theories about the concept of market orientation, competitive advantage and relationship marketing orientation can be seen in Figure 1.



Figure-1. Research conceptual model.

\section{RESEARCH HYPOTHESES}

Empirical studies show that market orientation has a direct and positive influence on the ability to innovate. Based on the results of the research conducted, market orientation positively affects additional service-related innovations and radical innovations, and it encourages the achievement of the subjective performance of a company. A competitor-oriented culture can increase innovation, as it is used to develop products that distinguish a company from its competitors. Market orientation has a positive and significant effect on innovation capability. Based on the opinions and results of previous studies, the following hypothesis is proposed:

H1: Market orientation has an effect on collaborative innovation capability.

The increasingly dynamic market competition demands that every company has the ability to innovate. Capacity to innovate is one of the most important factors that can affect business performance. Prajogo (2006) stated that the innovation of a process is strongly related to a company's performance. The need to collaborate through competitive methods to create innovation-oriented strategies is more important to maintaining survival. Product innovation has a positive and significant effect on marketing performance advantage.

Based on the opinions and results of previous studies, the following hypothesis is proposed:

H2: Innovation capabilities of collaborating has an effect on marketing performance.

Achieving market performance not only attracts and generates satisfied customers, but it also forms customer loyalty. Therefore, a company should be able to base their marketing on customer relationships. Relationship marketing emphasizes long-term interactive relationships between service providers and customers, bringing long-term benefits. Market orientation and relationship marketing orientation are two interconnected concepts and are under one philosophical umbrella of marketing. Through market orientation, the value and quality of service that customers receive increases and the company increases the level of value felt by employees, which ultimately results in a higher level of customer service quality. Market orientation is related to creating and satisfying the needs and desires of its customers. Based on the opinions and results of previous studies, the following hypothesis is proposed:

H3: Market orientation has an effect on relationship marketing orientation. 
The application of market orientation by a company has the potential to create advantages in customer knowledge, and this will be a source in creating products according to customer desires and needs. This can also be a source of competitive advantage, as market orientation is a complementary asset that contributes to the company's superior performance. Based on the opinions and results of previous studies, the following hypothesis is proposed:

\section{H4: Market orientation has an effect on competitive advantage.}

Companies are required to have the ability to build and maintain relationships with their customers in order to face dynamic market competition. Relationship marketing of a marketing concept emphasizes the creation and development of relationships with customers and stakeholders. Augusto and Coelho (2009) explained that the relationship marketing orientation of a company's technology resources serves to provide sustainable innovation performance. Codourey (2013) stated that relationship marketing orientation strategies, in addition to attracting new customers, also used continuous improvement and innovation. Moreover, Dingler and Enkel (2016) defined customer collaboration as a tool for obtaining information on customer preferences to suggest ideas for new product. Another study on relationship marketing proves theoretically and empirically that customer collaboration improves the success of innovation performance. The marketing orientation of the relationship consists of reciprocity, interdependency, commitment, as well as seller and buyer relationships, dissemination of market information, and coordination between functional information owned by the company. From this, it is possible to support the success of collaboration capabilities in innovation. Based on the opinions and results of previous studies, the hypothesis proposed in this study is as follows:

\section{H5: Relationship marketing orientation has an influence on the capability of collaborative innovation.}

Every competing company is required to think and act innovatively. Innovation is as a way for companies to adapt to their environment due to dynamic change. An innovative company has the ability to improve the performance of individuals, the performance of organization as a whole, and increase competitive advantage (Liao, $\mathrm{Wu}, \mathrm{Hu}, \&$ Tsuei, 2009). Larsen and Lewis (2007) explained that creative and innovative companies are more able to compete and survive in a competitive environment. Based on the opinions and results of previous studies, the hypothesis in this study is as follows:

H6: Collaboration innovation capabilities have an impact on competitive advantage.

As previously stated, business philosophy has shifted from production orientation to sales orientation and then to marketing orientation and finally to relationship marketing orientation. The establishment of a relationship between consumers and manufacturers will benefit all parties. Sin., Tse, Chan, Vincent, and Heung (2006) found that marketing orientation has a positive and significant effect on marketing performance. Moreover, Nguyen and Liem (2011) explained that the key components of relationship marketing orientation are trust, bonding, shared values, reciprocity, communication and empathy. Based on the opinions and results of previous studies, the hypothesis in this study is as follows:

H7: Relationship marketing orientation has an influence on marketing performance.

Having the ability to compete is the key to maintaining business performance in the long term in increasingly competitive conditions. Every business must have a competitive advantage in order to survive and operate efficiently. Some literature and studies have provided evidence that there is a positive relationship between the superiority of the competitive and the performance of marketing. Based on research conducted by Pardi, Imam, and Zainul (2014), finding competitive advantages can have a positive influence on marketing performance. Furthermore, (Strandskov, 2006) found that competitive advantages, such as firm-specific advantages and relationshipspecific advantages, have an effect on the success of a business. Based on the opinions and results of previous studies, the hypothesis in this study is as follows:

H8: Competitive advantage has an influence on marketing performance. 


\section{RESEARCH METHOD AND ANALYSIS}

\subsection{Research Design}

This research is aimed at improving scientific knowledge and finding new research fields that, in the long run, can be used to measure the impact of exogenous variables (e.g., market orientation) on endogenous variables (e.g., marketing performance) involving intervening variables (e.g., relationship marketing orientation), competitive advantage, and collaboration innovation capability, by analyzing SMEs in the woodcraft industry. The research population of woodcraft and furniture SMEs is based on businesses in North Hulu Sungai Regency using a sample of 242 respondents.

\subsection{Variable Operational Definitions}

a. Market orientation: the behavior of woodworking handicraft businesses in maintaining their business by fulfilling the needs of the current or future market, which is measured using the following indicators: information collection, dissemination of market information, and informational affairs.

b. Innovation capability collaboration: the ability of woodcraft businesses to build relationships with dealers and customers, and to work together continuously through the absorption of information and knowledge to innovate services, develop new products and determine new markets. This is measured using cooperation, information absorption, coordination of new ideas and the ability to innovate as indicators.

c. Competitive advantage: the ability of businesses to add value to their products compared to their competitors, which is measured using uniqueness/creativity, competitive price, originality, and reliability of service as indicators.

d. Relationship marketing orientation: a company's activities in creating, maintaining and improving longterm relationships with customers to provide mutual profit, measured using indicators including trust, bonding/connection, marketing communication, empathy and reciprocity.

e. Marketing performance: the ability of businesses to achieve marketing targets that have been set for a certain period of time by looking at sales levels, market coverage, the number of new customers and the level of profit of the company compared to competitors, measured using indicators including market coverage, sales value, increase in customers, and increase in company profit.

\section{DATA COLLECTION METHOD AND DATA ANALYSIS}

The method of data collection aims to demonstrate systematic scientific facilities by using personally administered questionnaires. In this study, data analysis was carried out using the partial least squares (PLS) model with the help of SmartPLS software. Furthermore, the test results of the significant influence between variables with the calculation of the t-statistics inner model structural fit can be seen in Table 1 and Figure 2.

Table 1 contains the outer loadings (convergent validity) test results on the latent construction items of market orientation [X1], collaboration innovation capability [X2], competitive advantage [X3], relationship marketing orientation [X4], and marketing performance [Y]. Next, hypothesis testing to determine any significant influence is carried out by comparing the t-statistics bootstrapping results with the t-values. The hypothetical test results can be seen in the final model of the research results in the form of the schematic in Figure 3, which is evidence of the presence of significant variable influences. The analysis of the first hypothesis tests the influence of market orientation $\left(\mathrm{X}_{1}\right)$ on the capability of collaborative innovation (X2). From the results, it is known that the tstatistical value of $1.976>1.96$. Because the t-statistical value is greater than the t-value, it can be concluded that market orientation has a significant positive effect on the capability of collaborative innovation at a rate of $5 \%$ significance, with a large influence (0.180 or $18.0 \%)$. 
Table-1. T-statistic inner model structural fit.

\begin{tabular}{l|c|c|c|c}
\hline Influence Between Constructs & $\begin{array}{c}\text { Path } \\
\text { coefficient }\end{array}$ & $\begin{array}{c}\text { T- } \\
\text { statistic }\end{array}$ & $\begin{array}{c}\text { T-Value } \\
\text { SmartPLS }\end{array}$ & T-Statistics \\
\hline $\begin{array}{l}\text { Market Orientation }>\text { Innovation Capabilities } \\
\text { Collaboration }\end{array}$ & 0.180 & 1.976 & 1.96 & Significant \\
\hline Market Orientation > Competitive Advantage & 0.095 & 1.344 & 1.96 & Insignificant \\
\hline $\begin{array}{l}\text { Market Orientation > Relationship Marketing } \\
\text { Orientation }\end{array}$ & 0.512 & 11.044 & 1.96 & Significant \\
\hline $\begin{array}{l}\text { Innovation Capabilities Collaboration > Competitive } \\
\text { Advantage }\end{array}$ & -0.463 & 8.975 & 1.96 & Significant \\
\hline $\begin{array}{l}\text { Innovation Capabilities Collaboration > Marketing } \\
\text { Performance }\end{array}$ & 0.147 & 1.897 & 1.96 & Insignificant \\
\hline $\begin{array}{l}\text { Competitive Advantage > Marketing Performance } \\
\text { Relationship Marketing Orientation > Innovation } \\
\text { Capabilities Collaboration }\end{array}$ & 0.331 & 5.764 & 1.96 & Significant \\
\hline $\begin{array}{l}\text { Relationship Marketing Orientation > Marketing } \\
\text { Performance }\end{array}$ & 0.075 & 0.849 & 1.96 & Significant \\
\hline
\end{tabular}

Figure 2 below shows the t-statistic bootstrapping analysis results.

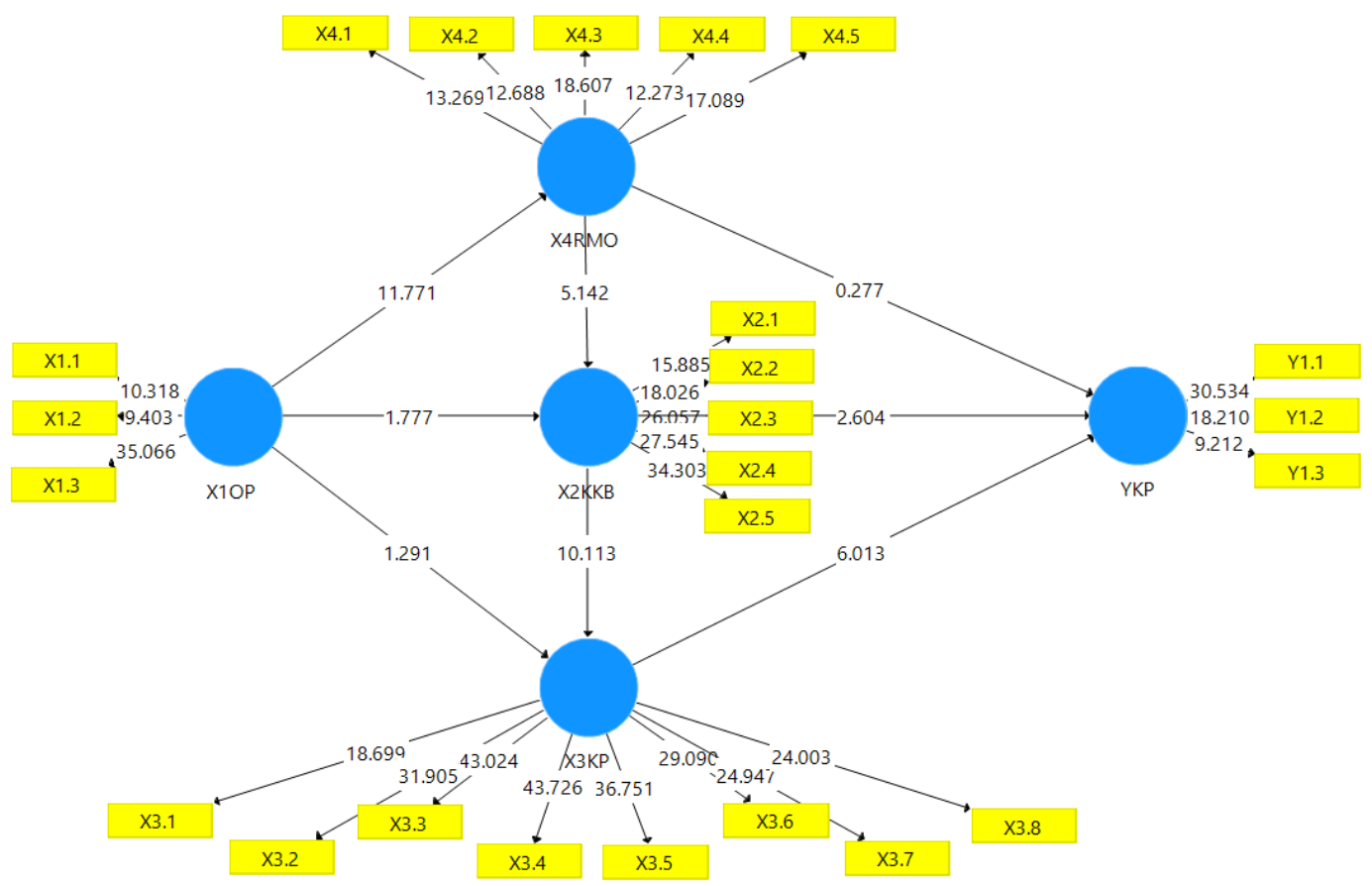

Figure-2. T-Statistic Bootstrapping Results (SmartPLS).



Figure-3. The model of hypotheses examination. 
This shows that market orientation is important for companies to support building innovation collaboration for woodworkers. The complexity of competition and the diversity of customer demand means that the craftsmen need to be committed to creating and innovating to ensure the superior quality of their products. The form of collaboration is determined by discussing ideas with dealers, hearing customer opinions, reviewing changes in the market environment, conducting customer satisfaction surveys, focusing on strengthening the culture of functional cooperation or coordinating strategies to ensure that the needs of new customers are met. Collaboration becomes an important strategy for small and medium enterprises (SMEs) to develop innovations because their resources are limited. Through her research, (Laforet, 2011) combined company size and strategic and market orientation factors as innovation predictors. Other studies that focus on market orientation and its relation to innovation include (Carmen \& José, 2008; Hilman \& Kaliappen, 2015). Findings of this study show that wood-oriented crafts in the market have an impact on the development of collaboration capabilities when innovating.

The analysis of the second hypothesis involved testing the influence of market orientation (X1) on competitive advantage (X3). From the results, it is known that the t-statistical value of $1.344<1.96$. Because the t-statistical value is smaller than the t-value, it can be concluded that market orientation has no significant effect on competitive advantage at the $5 \%$ significance level, with a great influence (0.95 or $0.95 \%)$. This shows the orientation of the existing market and that what has been done by the craftsmen of the woodworking industry has not been able to support the creation of a competitive advantage. The results of the above research show that woodworkers have not been maximally responsive to observing various problems and increasingly tight competition. The results of this study do not match the theory presented, where a corporate culture that emphasizes the importance of paying attention to the market orientation will lead to the strengthening of a company's competitive advantage. Contrary to the theory presented (Selnes, Jaworski, \& Kohli, 1996), where in its statement through market orientation allows the industry to explore and analyze the external environment in order to understand the pre-reference necessity of the market, how to coordinate the dissemination of information across functions and satisfying its customers as well as responding to changes regarding competitors and market potential. The results of this study also do not support the study by Narver and Slater (1990), where the greater the customer orientation, the more a company will be able to develop a competitive advantage based on differentiation of market necessity. Basically, businesses such as those in the woodworking industry must be market-oriented because with market-orientation it can build a systematic and comprehensive culture to commit sustainably to creating a competitive advantage that is finally able to improve the marketing performance of the woodworking industry.

Analysis of the third hypothesis involved testing the influence of market orientation (X1) on relationship marketing orientation $(\mathrm{X} 4)$. From the results, it is known that the t-statistical value of $11.044>1.96$. Because the tstatistical value is greater than the t-value it can be concluded that market orientation has a significant positive effect on relationship marketing orientations at a significance of 5\%, with a large influence (0.512 or $51.2 \%$ ). These objectives can be fulfilled by the way businesses foster good relationships with their customers, employees, suppliers, distributors and distribution partners because good relationships can determine the future of a company. With a view to building partnerships and providing the best quality for customers, a company can build long-term alliances with customers, suppliers, distributors and distribution partners through relationship marketing orientations (RMO) (Evans \& Laskin, 1994). To create a market-oriented company, woodcraft businesses must be able to meet every need of its customers. Through market orientation, product value and quality of service that customers may be concerned about will increase, and eventually the company will also increase the level of value for its employees, which means that the quality level of customer service becomes higher. Moreover, if a business adopts a relationship approach with its customers, it will have access to a quality source of marketing intelligence, which will help to improve their performance in a more competitive market (Olotu, Maclayton, \& Ahiauzu, 2011). Research conducted by Sin. et al. (2006) states that the key factors of success persist in a mature market and depend on maintaining long-term relationships with stakeholders (customers), employees, suppliers, and community 
representatives. Furthermore, market orientation and relational marketing orientation are both the right blend of a company that will produce a different level of performance compared to other companies.

The analysis of the fourth hypothesis tested the capability of collaborative innovation (X2) against competitive advantage (X4). From the results of the analysis, it is known that the t-statistical value of $8.975>1.96$. Because the t-statistical value is greater than the t-value, it can be concluded that the collaboration innovation capability negatively and significantly affects relationship marketing orientation at a significance level of $5 \%$, with a large influence (-0.463 or $-46.3 \%)$. The main objective of a company is the ability of innovation to meet market demand, so innovation becomes one of the strategies used to gain a competitive advantage. Companies that successfully build innovation capabilities through collaboration mean they are one step ahead of their competitors and can use these capabilities as a foundation for achieving long-term competitive advantage. The ability to innovate is a company's mechanism to adapt in a competitive environment. Therefore, every industry is required to create new thoughts and ideas and offer innovative products as well as improve the distribution service process in order to survive, keep customers satisfied and beat the competition. The ability to find creative new ideas and collaborative innovations for each product will create a competitive advantage.

Analysis of the fifth hypothesis tested collaboration innovation capability (X2) against marketing performance $(\mathrm{Y})$. The results of the analysis show that the t-statistical value is $1.897<1.96$. Because the t-statistical value is smaller than the t-value, it can be concluded that collaboration innovation capability has an insignificant effect on marketing performance at a significance of $5 \%$, with a large influence (0.147 or $1.47 \%)$. This shows that the collaboration innovation capability built so far by the players of the woodworking industry has not been able to support the improvement of marketing performance. The existing form of collaborative innovation capabilities still cannot improve from sustainable marketing performance. The form of innovation collaboration through dealers and customers with the aim of creating something new and diverse for product innovation, distribution services and determination of new market potential is not able to drive the improvement of marketing performance, which is reflected in the lack of an increase in sales profit. New customers and annual market share have not provided significant results, and many woodcrafters do not have the ability or competence to innovate and they have not been able to influence from their low ability level of collaboration innovation. The results of this study do not support what is conveyed by Wang and Ahmed (2007), which says the ability of companies to develop new products or markets through the alignment of strategic innovation orientation with innovative processes and behaviors is a form of collaboration capability of innovating.

Analysis of the sixth hypothesis tests the influence of competitive advantage (X3) on marketing performance $(\mathrm{Y})$. The results show that the t-statistical value of $5.764>1.96$. Because the t-statistical value is greater than the $t-$ value, it can be concluded that competitive advantage has a significant positive effect on marketing performance at a rate of $5 \%$ significance, with a large influence (0.331 or $33.1 \%$ ). To beat the competition and be able to improve marketing performance, it is not enough for businesses to be skilled in managing products, they must also build profitable customer relationships and achieve a competitive advantage.

The analysis of the seventh hypothesis tests the influence of relationship marketing orientation (X4) on collaborative innovation capabilities (X2). From the results of the analysis, it is known that the t-statistical value of $4.861>1.96$. Because the t-statistical value is greater than the t-value, it can be concluded that relationship marketing orientation has a significant positive effect on the innovation capability of collaborating at a significance level of $5 \%$, with a large influence (0.364 or 36.4\%). Increased competition, relentless turbulence, change, and uncertainty force organizations to build innovation capabilities, so the ability to innovate is an integral part of every company's strategy. A company's ability to develop and implement innovation has become a fundamental determinant of competitiveness for every SME. This study found that relationship marketing orientation is able to influence the ability to collaborate on innovation, which is in accordance with what is stated by (Augusto \& Coelho, 2009 ) - that the orientation of relationship marketing $(\mathrm{RM})$ is a technological resource of a company that serves to 
provide sustainable innovation performance. This is because relationship marketing orientation improves market sensing capabilities and quality customer relationships, and this capability can be assumed to improve the performance capabilities of higher innovations than those of competitor companies (Baker \& Sinkula, 1999). Therefore, innovation capabilities in SMEs can be sourced from external activities as well as internally in the industry. As a form of corporate behavior related to the external market environment, relationship marketing orientation can be used to anticipate and respond to the needs of customers and support success in innovating (Sharma \& Patterson, 1999). In addition, the theory from Bustinza, Gomes, Vendrell-Herrero, and Baines (2019) has stated that the strategic objectives of relationship marketing orientation are not only to attract new customers but also to retain them, which requires improvement and sustainable innovation capabilities. Whereas Naili, Naryoso, and Ardyan (2017) found that relationship marketing is able to maintain continuity in long-term relationships with consumers, suppliers, retailers and customers. Through marketing, the relationships will form a collaboration or relationship between suppliers, suppliers, retailers and customers to achieve innovation. This fact is reinforced by the response of $70.7 \%$ of respondents in this study, who stated that the intertwining of customer relationships and the channel plays a major role in developing new ideas to support and create innovation.

The results of this research are in line with those of Un and Asakawa (2015), who have proven that collaboration, especially external collaboration, improves the performance of a company's innovation. Relationship marketing orientation, which is characterized by reciprocity, interdependency, commitment, and long-term relationships between sellers and buyers, increases and disseminates market information by coordinating functional information owned by the company to create value for customers which can support success in building collaboration innovation.

The analysis of the eighth hypothesis tests the influence of relationship marketing orientation (X4) on marketing performance (Y). From the results of the analysis, it is known that the t-statistical value of $0.849<1.96$. Because the t-statistical value is smaller than the t-value, it can be concluded that relationship marketing orientation has no significant effect on marketing performance at a significance level of $5 \%$, with a large influence $(0.075$ or $0.75 \%)$. This result indicates that the activities of relationship marketing orientation conducted by the owners or managers of woodworking businesses in North Hulu Sungai Regency do not affect marketing performance. This means that although the activities of relationship marketing orientation (instilling trust and privacy, establishing relationships and periodic communication, addressing customer complaints, implementing effective marketing communications as well as caring about each customer's needs and desires) are done intensively, they will not impact the level of marketing performance of wood furniture handicrafts. Acquiring new customers is just as important as maintaining and improving relationships with current customers to achieve long-term marketing performance success. To increase demand, a business must meet customer expectations and maintain performance by creating permanent relationships with customers in addition to gaining new customers. The results of this study on relationship marketing orientation became part of the marketing management activities that are less effective so that the improvement of the activity does not impact the marketing performance for owners or craftsmen in the woodworking industry.

\section{CONCLUSION}

The results of the analysis concluded, Market orientation proved to have a positive and significant effect on innovation capabilities in collaboration, Relationship marketing orientation and competitive advantage. Collaborative innovation capabilities can positively affect marketing performance as well as competitive excellence. Relationship marketing orientation can positively affect significantly the capability of collaborative innovation and marketing performance. The advantages of competing positively are significantly able to influence marketing performance. Further results of this study found relationship marketing orientation proved to have no significant effect on competitive advantage, as well as for market orientation proved to have no significant effect on marketing 
performance. Based on the findings of its research capability on innovation collaborates, competitive advantages and relationship marketing orientation can be a booster in improving the marketing performance of wooden furniture handicrafts in Hulu Sungai Utara Regency. While the implementation of relationship marketing orientation that has been done by wood furniture artisans in Hulu Sungai Utara Regency has not given a meaningful contribution that is influence in creating competitive advantages. Moreover, marketing orientation that has been run by wood furniture artisans is also not able to influence the marketing performance of the wood furniture industry in Hulu Sungai Utara Regency.

\section{LIMITATIONS AND FUTURE RESEARCH}

This research focuses only on industrial groups in the field of wood furniture handicrafts and with representatives or samples is very limited in number, so the generalization of the results of this research must be done carefully. Further research should take more broad objects and more samples so that the research results can be generalized better, especially the more complete competition and high dynamics of marketing performance in the small industry craft furniture and other variables that affect it is always changing as the environment changes. Furthermore, the new concept of innovation capability in collaboration needs to be studied more deeply in the business sector or other business fields, such as service sector industry, batik handicraft industry, rattan furniture or home food industry of local products for further researchers. Future research may expand the area or object of more general research and larger respondents.

Funding: This research was organized with financial support from the government of the Republic of Indonesia through the Director General of Higher Education/National Innovative Research Agency Kementerian Riset Teknologi Dan Pendidikan Tinggi Republik Indonesia;Kementerian Riset Teknologi Dan Pendidikan Tinggi Republik Indonesia; in 2020.

Competing Interests: The authors declare that they have no competing interests.

Acknowledgement: All authors contributed equally to the conception and design of the study.

\section{REFERENCES}

Augusto, M., \& Coelho, F. (2009). Market orientation and new-to-the-world products: Exploring the moderating effects of innovativeness, competitive strength, and environmental forces. Industrial Marketing Management, 38(1), 94-108. Available at: https://doi.org/10.1016/j.indmarman.2007.09.007.

Baker, W. E., \& Sinkula, J. M. (1999). Learning orientation, market orientation, and innovation: Integrating and extending models of organizational performance. Journal of Market-Focused Management, 4(4), 295-308. Available at: https://doi.org/10.1023/A:1009830402395.

Bustinza, O. F., Gomes, E., Vendrell-Herrero, F., \& Baines, T. (2019). Product-service innovation and performance: The role of collaborative partnerships and R\&D intensity. RङD Management, 49(1), 33-45. Available at: https://doi.org/10.1111/radm.12269.

Carmen, C., \& José, G. M. (2008). The role of technological and organizational innovation in the relation between market orientation and performance in cultural organizations. European Journal of Innovation Management, 11, 423-434. Available at: https://doi.org/10.1108/14601060810889035.

Codourey, M. (2013). The public handshake, the pushed gossip and the healthcare marketing. Economics and Sociology, 6, 11-27. Available at: https://doi.org/10.14254/2071-789X.2013/6-2/2.

Day, G. S., \& Wensley, R. (1988). Assessing advantage: A framework for diagnosing competitive superiority. Journal of Marketing, 52(2), 1-20. Available at: https://doi.org/10.2307/1251454.

Deshpandé, R., \& Farley, J. U. (1998). Measuring market orientation: Generalization and synthesis. Journal of Market-Focused Management, 2(3), 213-232. Available at: https://doi.org/10.1023/A:1009719615327.

Dingler, A., \& Enkel, E. (2016). Socialization and innovation: Insights from collaboration across industry boundaries. Technological Forecasting and Social Change, 109, 50-60. Available at: https://doi.org/10.1016/j.techfore.2016.05.017. 
Dyhdalewicz, A., \& Widelska, U. (2017). Accounting and marketing dimensions of innovations. e-Finanse: Financial Internet Quarterly, 13(2), 1-13. Available at: https://doi.org/10.1515/fiqf-2016-0018.

Ehmke, C. (2008). Strategies for competitive advantage. Niche Markets: Assessment and Strategy Development for Agriculture, 08-13.

Evans, J. R., \& Laskin, R. L. (1994). The relationship marketing process: A conceptualization and application. Industrial Marketing Management, 23(5), 439-452. Available at: https://doi.org/10.1016/0019-8501(94)90007-8.

Farida, N., \& Yuniawan. (2017). Model of relationship marketing partnerships between Batik SMEs and Batik Distributors in Central Java, Indonesia. International Journal of Social Ecology and Sustainable Development, 6(4), 1-14. Available at: https://doi.org/DOI:10.4018/IJSESD.2017100101.

Ferdinand, A. (2002). Marketing strategy making: Proses \& agenda penelitian. Indonesian Journal of Marketing Science, 1(1), 1-22. Available at: https://doi.org/10.14710/jspi.v1i1.1-22.

Fransisca, W. M. (2013). The effect of the board of directors, independent commissioners, audit committee, managerial ownership and institutional ownership on financial performance. Journal of Management Science (JIM), I(1), $234-247$.

Hassan, M., Shaukat, S., Nawaz, M. S., \& Naz, S. (2013). Effects of innovation types on firm performance: An empirical study on Pakistan's manufacturing sector. Pakistan Journal of Commerce and Social Sciences (PJCSS), 7(2), 243-262.

Hilman, H., \& Kaliappen, N. (2015). Innovation strategies and performance: Are they truly linked? World Journal of Entrepreneurship, Management and Sustainable Development, 11(1), 48-63. Available at: https://doi.org/10.1108/wjemsd04-2014-0010.

Huhtala, J.-P., Sihvonen, A., Frösén, J., Jaakkola, M., \& Tikkanen, H. (2014). Market orientation, innovation capability and business performance: Insights from the global financial crisis. Baltic Journal of Management, 9(2), 134-152. Available at: https://doi.org/10.1108/BJM-03-2013-0044.

Laforet, S. (2011). A framework of organisational innovation and outcomes in SMEs. International Journal of Entrepreneurial Behavior \& Research, 17(4), 380-408. Available at: https://doi.org/10.1108/13552551111139638.

Larsen, P., \& Lewis, A. (2007). How award-winning SMEs manage the barriers to innovation. Creativity and Innovation Management, 16(2), 142-151. Available at: https://doi.org/10.1111/j.1467-8691.2007.00428.x.

Liao, S.-H., Wu, C.-C., Hu, D.-C., \& Tsuei, G. A. (2009). Knowledge acquisition, absorptive capacity, and innovation capability: An empirical study of Taiwan's knowledge-intensive industries. Technology, 11(53), 160-167.

Naili, F., Naryoso, A., \& Ardyan, E. (2017). Model of relationship marketing partnerships between Batik SMEs and batik distributors in Central Java, Indonesia. International Journal of Social Ecology and Sustainable Development (IJSESD), 8(4), 1-14. Available at: https://doi.org/10.4018/IJSESD.2017100101.

Narver, J. C., \& Slater, S. F. (1990). The effect of a market orientation on business profitability. Journal of Marketing, 54(4), $20-35$. Available at: https://doi.org/10.1177/002224299005400403.

Nguyen, H., \& Liem, V. N. (2011). Relationship marketing in Vietnam : An empirical study. Asia Pacific Journal of Marketing and Logistics, 24(2), 222-235. Available at: https://doi.org/10.1108/13555851211218039.

Olotu, O. A., Maclayton, D. W., \& Ahiauzu, A. I. (2011). Empirical evidence for a sociality factor in relationship marketing orientation scale in the Nigerian banking sector. European Journal of Social Sciences, 27(1), 104-1 12.

Parasuraman, A., Zeithaml, V. A., \& Malhotra, A. (2005). E-S-QUAL a multiple-item scale for assessing electronic service quality. Journal of Service Research, 7(3), 213-233. Available at: https://doi.org/10.1177/1094670504271156.

Pardi, S., Imam, S., \& Zainul, A. (2014). The effect of market orientation and entrepreneurial orientation toward learning orientation, innovation, competitive advantages and marketing performance. European Journal of Business and Management, 6(21), 69-80.

Paulraj, A., Lado, A. A., \& Chen, I. J. (2008). Inter-organizational communication as a relational competency: Antecedents and performance outcomes in collaborative buyer-supplier relationships. Journal of Operations Management, 26(1), 45-64. Available at: https://doi.org/10.1016/j.jom.2007.04.001.

Prajogo, D. I. (2006). The relationship between innovation and business performance a comparative study between manufacturing and service firms. Knowledge and Process Management, 13(3), 218-225. 
Russo-Spena, T., \& Mele, C. (2012). "Five Co-s" in innovating: A practice-based view. Journal of Service Management, 23(8), 17575818. Available at: https://doi.org/10.1108/09564231211260404.

Selnes, F., Jaworski, B. J., \& Kohli, A. K. (1996). Market orientation in United States and Scandinavian companies. A crosscultural study. Scandinavian Journal of Management, 12(2), 139-157. Available at: https://doi.org/10.1016/09565221(95)00053-4.

Sharma, N., \& Patterson, P. G. (1999). The impact of communication effectiveness and service quality on relationship commitment in consumer, professional services. Journal of Services Marketing, 13(2), 151-170. Available at: https://doi.org/10.1108/08876049910266059.

Sin, L. Y., Tse, A. C., Yau, O. H., Chow, R. P., \& Lee, J. S. (2005). Market orientation, relationship marketing orientation, and business performance: The moderating effects of economic ideology and industry type. Journal of International Marketing, 13(1), 36-57. Available at: https://doi.org/10.1509/jimk.13.1.36.58538.

Sin., L. Y. M., Tse, A. C. B., Chan, H., Vincent, C. S., \& Heung, F. H. K. Y. (2006). The effects of relationship marketing orientation on business performance in the hotel industry. Journal Of Hospitality \& Tourism Research, 30(4), 407-426. Available at: https://doi.org/10.1177/1096348006287863.

Singh, A. K., \& Kumar, S. (2021). Assessing the performance and factors affecting industrial development in Indian States: An empirical analysis. Journal of Social Economics Research, 8(2), 135-154. Available at: https://doi.org/10.18488/journal.35.2021.82.135.154.

Strandskov, J. (2006). Sources of competitive advantages and business performance. Journal of Business Economics and Management, 7(3), 119-129.

Un, C. A., \& Asakawa, K. (2015). Types of R\&D collaborations and process innovation: The benefit of collaborating upstream in the knowledge chain. Journal of Product Innovation Management, 32(1), 138-153. Available at: https://doi.org/10.1111/jpim.12229.

Wang, C. L., \& Ahmed, P. K. (2007). Dynamic capabilities: A review and research agenda. International Journal of Management Reviews, 9(1), 31-51. Available at: https://doi.org/10.1111/j.1468-2370.2007.00201.x.

Xu, H., Wang, C., Dong, K., Luo, R., Yue, Z., \& Pang, H. (2020). A study of methods to identify industry-university-research institution cooperation partners based on innovation Chain theory. Journal of Data and Information Science, 3(2), 38-61. Available at: https://doi.org/10.2478/jdis-2018-0008.

Zheng, Y., Zhang, L., Ma, Z., Xie, X., \& Ma, W. Y. (2011). Recommending friends and locations based on individual location history. ACM Transactions on the Web, 5(1), 1-44. Available at: https://doi.org/10.1145/1921591.1921596.

Zhou, K. Z., Yim, C. K., \& Tse, D. K. (2005). The effects of strategic orientations on technology-and market-based breakthrough innovations. Journal of Marketing, 69(2), 42-60. Available at: https://doi.org/10.1509/jmkg.69.2.42.60756

Views and opinions expressed in this article are the views and opinions of the author(s), Humanities and Social Sciences Letters shall not be responsible or answerable for any loss, damage or liability etc. caused in relation to/arising out of the use of the content. 